\title{
1. An internally displaced person described
}

\section{INTRODUCTION}

Who is an internally displaced person (IDP)? Three decades ago, when the issue of internal displacement came on the global scene as an imperative agenda, one of the pertinent issues was describing this category. Without doubt, the notion of IDPs meant that these were persons in movement situations that were not cross-border. As such, neither the definition of the $1951 \mathrm{UN}$ Refugee Convention nor its 1967 Protocol was applicable. ${ }^{1}$ But there was also an understanding that the patterns of movement could be similar as persons could be fleeing a well-founded fear of persecution from a region of a country to another. However, the international legal definition of refugees could not apply to IDPs. Moreover, the definition did not fully capture the experiences of IDPs and does not contemplate movement situations that are not solely premised on a well-founded fear of persecution on the basis of 'race, religion, nationality, membership of particular social groups or political opinion'. ${ }^{2}$

In the years following the adoption of the 1951 UN Refugee Convention and its 1967 Protocol, other regional frameworks have alluded to situations that may also result in the flight of persons, as such expanding on the refugee definition. ${ }^{3}$ For instance, the 1969 OAU Refugee Convention also recognises as

\footnotetext{
1 UN Refugee Convention Relating to the Status of Refugees 1951 (1951 UN Refugee Convention); Protocol Relating to the Status of Refugees 1967 (1967 UN Refugee Protocol).

21951 UN Refugee Convention (n 1), art 1(2).

3 OAU Convention Governing the Specific Aspects of Refugee Problems in Africa 1001 UNTS 45 (1969 OAU Refugee Convention); Cartagena Declaration on Refugees, Colloquium in the International Protection of Refugees in Central America, Mexico and Panama (19-22 November 1984); Austin T Fragomen Jr 'The Refugee: A Problem of Definition' (1970) Case Western Reserve Journal of International Law 45; Peter Nobel 'Refugees, Law, and Development in Africa' (1982) 3 Michigan Journal of International Law 255; Atle Grahl-Madsen 'Identifying the World's Refugees' (1983) The Annals of the American Academy of Political and Social Science 11; Eduardo Arboleda 'Refugee Definition in Africa and Latin America: The Lessons of Pragmatism' (1991) 3(2) International Journal of Refugee Law 185; Rainer Hofmann 'Refugee Law in the African Context' (1992) 52 Heidelberg Journal of International Law 318; Emmanuel O Awuku 'Refugee Movements in Africa and
} 
refugees, 'every person who, owing to external aggression, occupation, foreign domination or events seriously disturbing public order in either part or the whole of his country of origin or nationality, is compelled to leave his place of habitual residence in order to seek refuge in another place outside his country of origin or nationality'. ${ }^{4}$ Similarly, under the 1984 Cartagena Declaration on Refugees, refugees are persons who have 'fled their country because their lives, safety or freedom have been threatened by generalized violence, foreign aggression, internal conflicts, massive violation of human rights or other circumstances which have seriously disturbed public order'. ${ }^{5}$

These expanded refugee definitions reflect a progressive understanding of situations that occasion displacement, beyond what was initially contained in the 1951 Refugee Convention. When a global conversation on internal displacement subsequently emerged, this progressive understanding was infused into the description of IDPs. A fair sense of this resonates in the working description that was contained in the 1992 Analytical Report of the UN Secretary-General (UNSG). ${ }^{6}$

the OAU Convention on Refugees' (1995) 39(1) Journal of African Law 79; Bonaventure Rutinwa 'The End of Asylum? The Changing Nature of Refugee Policies in Africa' (2002) 21(1) Refugee Survey Quarterly 12; Alice Edwards 'Refugee Status Determination in Africa' (2006) 14 African Journal of International and Comparative Law 204-33; Guy S Goodwin-Gill and Jane McAdam The Refugee in International Law (Oxford University Press, 2007); Marina Sharpe 'The 1969 African Refugee Convention: Innovations, Misconceptions, and Omissions' (2012) 58(1) McGill Law Journal 95, 113; David J Cantor and Stefania E Barichello 'Protection of Asylum-Seekers Under the Inter-American Human Rights System' in Ademola Abass and Francesca Ippolito (eds) Regional Approaches to the Protection of Asylum Seekers: An International Legal Perspective (Taylor \& Francis, 2014) 267; James C Hathaway and Michelle Foster The Law of Refugee Status (Cambridge University Press, 2014); Tamara Wood 'Expanding Protection in Africa? Case Studies of the Implementation of the 1969 African Refugee Convention's Expanded Refugee Definition' (2014) 26(4) International Journal of Refugee Law 555; Carlos M Castillo 'The Cartagena Process: 30 Years of Innovation and Solidarity' (2015) 49 Forced Migration Review 89; Penelope Mathew and Tristan Harley Refugees, Regionalism and Responsibility (Edward Elgar Publishing, 2016); Cristiano D’Orsi Asylum-Seeker and Refugee Protection in Sub-Saharan Africa: The Peregrination of a Persecuted Human Being in Search of a Safe Haven (Routledge, 2016); Susan Kneebone 'Comparative Regional Protection Frameworks for Refugees: Norms and Norm Entrepreneurs' (2016) 20(2) The International Journal of Human Rights 153; José H Fischel de Andrade 'The 1984 Cartagena Declaration: A Critical Review of Some Aspects of its Emergence and Relevance' (2019) 38(4) Refugee Survey Quarterly 341.

$4 \quad 1969$ OAU Refugee Convention (n 3).

5 Cartagena Declaration (n 3).

6 UN Commission on Human Rights, Analytical Report of the Secretary-General on Internally Displaced Persons, UN Doc E/CN.4/1992/23. 
In this report, IDPs are described as: ${ }^{7}$

persons who have been forced to flee their homes suddenly or unexpectedly in large numbers; as a result of armed conflict, internal strife, systematic violations of human rights or natural or man-made disasters; and who are within the territory of their own country.

Notably, this working description recognises a wide array of possible causes of internal displacement. The inclusion of armed conflict and internal strife reflects the prevalence of these causes as drivers of large population movements within state borders. In the 1990s, these were extant realities in the South Caucasus (Armenia, Azerbaijan and Georgia) following the Cold War, ${ }^{8}$ in Iraq following the Gulf War, ${ }^{9}$ in the Northern Triangle of Central America, particularly Guatemala and El Salvador with civil wars, ${ }^{10}$ and in African countries with ethnic strife such as in the Sudan and Rwanda. ${ }^{11}$

\footnotetext{
7 ibid, para 17.

8 Kenneth H Bacon 'Lost in Purgatory: The Plight of Displaced Persons in the Caucasus' (2002/2003) 19(4) World Policy Journal 66.

9 United Nations High Commissioner for Refugees The State of the World's Refugees:
} Fifty Years of Humanitarian Action (2000) 212; Ilene R Prusher 'Turkey braces for refugee flood' The Christian Science Monitor 29 January 2003; Human Rights Watch Iraqi Refugees, Asylum Seekers, and Displaced Persons: Current Conditions and Concerns in the Event of War A Human Rights Watch Briefing Paper (February 2003); Monette Zard 'Towards a Comprehensive Approach to Protecting Refugees and the Internally Displaced' in Anne F Bayefsky (ed) Human Rights and Refugees, Internally Displaced Persons and Migrant Workers: Essays in Memory of Joan Fitzpatrick and Arthur Helton (Martinus Nijhoff Publishers, 2006) 15, 26; Yaniv Voller The Kurdish Liberation Movement in Iraq: From Insurgency to Statehood (Routledge, 2014) 69.

10 Peter Sollis 'Displaced Persons and Human Rights: The Crisis in El Salvador' (1992) 11(1) Bulletin of Latin American Research 49; Larry Rohter 'Honduras Confronts Military Atrocities of the 80's' The New York Times (21 December 1995); Susanne Schmeidl 'Conflict and Forced Migration: A Quantitative Review, 1964-1995' in Aristide R Zolberg and Peter M Benda (eds) Global Migrants, Global Refugees: Problems and Solutions (Berghahn Books, 2001) 62, 71; EJ Wood Insurgent Collective Action and Civil War in El Salvador (Cambridge University Press, 2003) 8; Meghan Bradley 'Forced Migration in Central America and the Caribbean: Cooperation and Challenges' in Elena Fiddian-Qasmiyeh, Gil Loescher, Katy Long and Nando Sigona (eds) The Oxford Handbook of Refugees and Forced Migration Studies (Oxford University Press, 2014) 664, 666; Molly Todd Beyond Displacement: Campesino, Refugees, and Collective Action in the Salvadoran Civil War (University Wisconsin Press, 2010); Sarnarata Reynolds 'It's a Suicide Act to Leave or Stay': Internal Displacement in El Salvador Refugee International Field Report (30 July 2015).

11 Larry Minear and Randolph C Kent 'Rwanda's Internally Displaced: A Conundrum Within a Conundrum' in Roberta Cohen and Francis M Deng (eds) The Forsaken People: Case Studies of the Internally Displaced (Brookings Institution Press, 1998) 57; Hiram A Ruiz 'The Sudan: Cradle of Displacement' in Roberta 
Aside from armed conflict and internal strife, the recognition of systematic human rights violations as a driver of internal displacement is significant given that it affords a premise on which to contextualise a wide range of issues that may not fall squarely within armed conflict and internal strife. In the UNSG Analytical Report, displacements due to actions of states and non-state groups such as torture, assassinations and enforced disappearances are some recognisable forms of this root cause. ${ }^{12}$ Systematic human rights violations as a context for framing internal displacement affords a premise on which to include pertinent issues that may create displacement concerns such as gender-based violence or harmful practices, although the latter is specifically recognised within the African regional framework on internal displacement. Moreover, it reinforces the centrality of human rights protection as closely linked with addressing internal displacement. A recognition, which incorporates a plethora of human rights norms.

As drivers of internal displacement, natural or manmade disasters are gaining interest, also with the increasing impact of climate change. ${ }^{13}$ There is also a sense in which natural disasters may intersect with manmade disasters; for instance, in situations where a country in a famine situation prevents humanitarian relief from reaching affected populations ${ }^{14}$ or where 'the response of the government in providing assistance may be affected by discriminatory practices'. ${ }^{15}$ It has been argued that "many "natural" disasters are in reality "manmade". ${ }^{16}$

While the UNSG's description was considered 'a good starting point', ${ }^{17}$ it raised some concerns. For instance, it emphasises sudden or unexpected movements in large numbers which create the difficulty of quantification and the likelihood of small groups of displaced persons being excluded. Moreover, it

Cohen and Francis M Deng (eds) The Forsaken People: Case Studies of the Internally Displaced (Brookings Institution Press, 1998) 139.

12 UN Commission on Human Rights, Analytical Report of the Secretary-General on Internally Displaced Persons (n 6), para 39.

13 Norwegian Refugee Council Climate change: people displaced (Norwegian Refugee Council, 2009).

14 Catherine Phuong The International Protection of Internally Displaced Persons (Cambridge University Press, 2005) 30.

15 Francis Deng 'Dealing with the Displaced: A Challenge to the International Community' (1995) 1(1) Global Governance 45, 49.

16 ibid, 49.

17 UN Commission on Human Rights, Comprehensive study on the human rights issues related to internally displaced persons, prepared by Mr. Francis M. Deng, Representative of the Secretary-General, UN Doc E/CN.4/1993/35 (21 January 1993), para 35 . 
creates the challenge of 'subjective evaluation'.$^{18}$ Another aspect of ambiguity relates to the conceptual notion of 'own country'. ${ }^{19}$ There are some questions this raises particularly in the context of statelessness and nationality. However, these concerns were subsequently addressed in the final text of the UN Guiding Principles on Internal Displacement (Guiding Principles). ${ }^{20}$ It is pertinent to emphasise that the Guiding Principles offers a 'descriptive identification'21 and not a legal definition as its objective "is not to create a new legal category to which rights and obligations would be attached, but to improve the legal protection of the internally displaced' ${ }^{22}$ In paragraph 2 of its introduction, the Guiding Principles describes an IDP as: ${ }^{23}$

persons or groups of persons who have been forced or obliged to flee or to leave their homes or places of habitual residence, in particular as a result of or in order to avoid the effects of armed conflict, situations of generalized violence, violations of human rights or natural or human-made disasters, and who have not crossed an internationally recognized state border.

There are six key elements of this description that are crucial to discuss. The notion of 'persons or groups of persons', 'forced or obliged to flee or to leave', 'homes or places of habitual residence', 'in particular' 'as a result of or in order to avoid the effects' of various root causes and 'who have not crossed an internationally recognized state border'. These core elements of the IDP description are discussed in this chapter.

\footnotetext{
18 ibid.

19 UN Commission on Human Rights, Analytical Report of the Secretary-General on Internally Displaced Persons (n 6), para 13.

20 UN Commission on Human Rights, Addendum, 'Guiding Principles on Internal Displacement' Report of the Representative of the Secretary-General, Mr. Francis M. Deng, submitted pursuant to Commission on Human Rights resolution 1997/39, UN Doc. E/CN.4/1998/53/Add.2 (11 February 1998) (the Guiding Principles).

${ }_{21}$ Walter Kälin 'Guiding Principles on Internal Displacement: annotations' Studies in Transnational Legal Policy No 38, The American Society of International Law (2008), para 3.

22 Catherine Phuong The International Protection of Internally Displaced Persons (n 14), 57.

23 UN Commission on Human Rights, Addendum, 'Guiding Principles on Internal Displacement' (n 20), para 2.
} 
It is useful to appreciate the notion of 'persons or groups of persons' in the IDP description. In plain terms, a 'person' is 'a human as an individual'. ${ }^{24}$ While this is generally acceptable as a clear and unambiguous ordinary definition of the term, there are three main complexities of this notion. The first relates to the categorisation of persons and the extent to which this notion is fluid given the legal variations of the term.

There is another layer of ambiguity as to whether nationality is integral to the recognition of 'persons' within the IDP context. In order words, can a refugee qualify as 'persons' within the IDP context, if, for instance, such person is displaced within the borders of the state of asylum or can a stateless person be recognised as a 'person' even while such individual may not be considered a national by operation of a state's law? Similar questions resonate from an appreciation of whether the description also covers migrants. Nowhere in this description are these complexities resolved. Yet, addressing these questions are important, particularly in providing clarity. Moreover, there is also the question as to whether 'persons or groups of persons' can be used to refer to an individual or if the usage of the plural form excludes an individualised conception and as such, must begin with at least two people.

To begin with, it is useful to reflect on the notion of personhood from a legal standpoint. In law, a person can be natural or juridical. ${ }^{25}$ While a natural person is a human being, a juridical person is a non-human entity, howbeit recognised in law as a person. Under various national laws, the use of the words 'persons', aside from natural persons, has been understood to include: corporations, animals and the environment. Courts have long recognised corporation as legal persons with this recognition also contained in many national legislations. Moreover, the notion of 'persons' has also been extended to animals, notably in Indian courts. In Karnail Singh and others $v$ State of Hayana, the High Court of Punjab and Haryana declared the 'entire animal kingdom including avian and aquatic' as 'legal entities having a distinct persona with corresponding rights, duties and liabilities of a living person'. ${ }^{26}$ In 2017 New Zealand adopted a legislation recognising the Te Awa Tupua (the Whanganui River) as a legal

24 'Person' Oxford Learner's Dictionaries https://www.oxfordlearnersdictionaries .com/definition/english/person?q=persons (accessed 21 March 2020).

25 Elvia AQ Adriano 'Natural Persons, Juridical Persons and Legal Personhood' (2015) 8 Mexican Law Review 101; Elvia AQ Adriano 'The Natural Person, Legal Entity or Juridical Person and Juridical Personality’ (2015) 4(1) Penn State Journal of Law and International Affairs 363.

26 Karnail Singh and others $v$ State of Hayana (Punjab and Haryana High Court, CRR-533-2013, 31 May 2019). 
person. ${ }^{27}$ While the notion of persons varies within various national contexts, the pertinent question which resonates is whether the notion of persons in the description relates to subjects other than natural persons. Going by the objective of the Guiding Principles, persons or groups of persons are individuals/human beings who are 'forced or obliged to flee or to leave their homes or places of habitual residence'. An extension of the word 'persons' to non-human entities will potentially detract from the context of the instrument, as such creating an ambiguity given that the instrument contemplates natural persons.

Moreover, it is useful to consider whether persons or groups of persons solely refer to nationals and citizens of a country. Some national IDP frameworks seem to suggest nationality as a precondition for inclusion within this context. For instance, the 2009 Sudan National Policy for IDPs uses the word 'Sudanese citizens' 28 in the preamble as opposed to 'persons or groups of persons' in the Guiding Principles. Moreover, Georgia's 2014 law on IDPs from the Occupied Territories of Georgia uses 'citizens of Georgia or a stateless person having a status in Georgia' ${ }^{29}$ The Ukrainian law is more expansive in that it provides that an IDP is a 'citizen of Ukraine, foreigner or stateless person who legally stays on the territory of Ukraine and has a right to permanent residence in Ukraine' ${ }^{30}$ However, the Guiding Principles does not

27 Article 14 of the Te Awa Tupua (Whanganui River Claims Settlement) Act provides that '(1) Te Awa Tupua is a legal person and has all the rights, powers, duties, and liabilities of a legal person. (2) The rights, powers, and duties of Te Awa Tupua must be exercised or performed, and responsibility for its liabilities must be taken, by Te Pou Tupua on behalf of, and in the name of, Te Awa Tupua, in the manner provided for in this Part and in Ruruku Whakatupua-Te Mana o Te Awa Tupua.' See Te Awa Tupua (Whanganui River Claims Settlement) Act 2017, art 14; Christopher Rodgers 'A New Approach to Protecting Ecosystems: The Te Awa Tupua (Whanganui River Claims Settlement) Act 2017' (2017) 19(4) Environmental Law Review 266; Aikaterini Argyrou and Harry Hummels 'Legal Personality and Economic Livelihood of the Whanganui River: A Call for Community Entrepreneurship' (2019) 44 (6/7) Water International 752.

28 Sudan: National Policy for Internally Displaced Persons (2009).

29 Article 6(1) provides that an IDP is a 'citizen of Georgia or a stateless person with a status residing in Georgia shall be considered as an IDP, if he/she was forced to leave his/her permanent place of residence because of threat to his/her or his/her family member's life, health or freedom caused by the occupation of the territory by a foreign state, aggression, armed conflict, mass violence and/or massive human rights violations and/or he/she cannot return to his/her permanent place of residence due to the above- mentioned reasons'. See Georgia: Law on internally Displaced Persons from the Occupied Territories of Georgia (2014), Article 6(1).

30 Ukraine: Law No 1706-VII, on Ensuring of Rights and Freedoms of Internally Displaced Persons (2014), Article 1; Council of Europe Enhancing the national legal framework in Ukraine for protecting the human rights of internally displaced persons (2016). 
qualify the notion of persons with terms that underpin citizenship, nationality or legal residence as preconditions. As such persons may include: citizens, non-citizens, refugees, stateless persons, migrants and returnees.

Although the word 'persons' is utilised in a plural form in the Guiding Principles, its plurality in the text does not preclude an individualised case, as for instance, where a person flees gender-based violence. Such a person could be an IDP in the context of human rights violations. What is imperative to underscore in the description is not so much the plurality, rather it is whether a person fits the description. Moreover, the imperative of avoiding the imprecision of quantification was essentially the reason why the initial description proposed in the Analytical Report was revised. Introducing such within this context will reintroduce the mischief sought to be addressed. Though in most situations of internal displacement there are often large population movements, there can be individualised cases of persons forced or obliged to flee their home or places of habitual residence.

\section{FORCED OR OBLIGED TO FLEE OR TO LEAVE}

Applying the ordinary meaning rule, the notion of being forced or obliged to flee contemplates an element of coercion or involuntariness. It is imperative to bifurcate four categories of movement that may be discerned from the IDP description, namely: (i) persons forced to flee, (ii) persons obliged to flee, (iii) persons forced to leave, and (iv) persons obliged to leave.

To begin, it is pertinent to differentiate two angles: forced and obliged. The first angle are persons forced. This involves an element of compulsion either premised on physical strength, violent action, strong influence or authority. ${ }^{31}$ The second angle relates to persons obliged. As with force, being obliged also contemplates a variance of will; however, this may arise from a sense of duty, law or seeking to render help or assistance, ${ }^{32}$ hence coming from a place of magnanimity and understanding. However, the semantic difference will depend on whether being forced or obliged relates to the terms flee or leave. Although both words are similar in that they both contemplate the act of movement, a difference that ought to be appreciated is the fact that the word 'leave' may be premised on a plethora of reasons for movement, as it also involves synonymic phrases such as to 'go away'. ${ }^{33}$ However, fleeing contemplates the

31 'Force' Oxford Learner's Dictionaries https://www.oxfordlearnersdictionaries .com/definition/english/force_1?q=force (accessed 21 March 2020).

32 'Oblige' Oxford Learner's Dictionaries https://www.oxfordlearnersdictionaries .com/definition/english/oblige? $q=$ oblige (accessed 21 March 2020).

33 'Leave' Oxford Learner's Dictionaries https://www.oxfordlearnersdictionaries .com/definition/english/leave_1?q=leave (accessed 21 March 2020). 
act of movement that is quick and either due to danger or fear. ${ }^{34}$ In all four scenarios, coercion and/or involuntariness is evident given that they involve movement either due to compulsion, an apparent danger or fear that induces flight or a sense of duty.

But there is a question which this description does not seem to provide explicit clarity on, which is the scenario in which persons move from their homes or places of habitual residence to other places prior to situations of internal displacement but cannot return to their homes or places of habitual residence due to natural disasters or situations of generalised violence. In the context of refugee law, such persons are generally regarded as 'sur place refugees' where they meet the definition under international refugee law. However, within the context of internal displacement, there is no explicit clarity on such a situation. Arguably, however, these persons may be regarded as 'sur place' IDPs. ${ }^{35}$

\section{HOMES OR PLACES OF HABITUAL RESIDENCE}

The Guiding Principles do not offer explicit guidance in understanding what homes or places of habitual residence entail. Going by their ordinary meaning, 'homes' or 'places of habitual residence' contemplate a degree of habitation that is either permanent or regular. In the context of property ownership or indigenous territories, the factual certainty of habitual residence is clear. However, there are some challenges that this notion does not resolve. For instance, in a situation where a person displaced from a particular land is considered to be a squatter, a pertinent question is whether such person can be regarded as having been displaced from a place of habitual residence. In answering this question, it is useful to consider what habitual residence implies. While this phrase is also employed in refugee law, ${ }^{36}$ it has prominently been discussed in the context of the Hague Convention on the Civil Aspects

34 'Flee' Oxford Learner's Dictionaries https://www.oxfordlearnersdictionaries .com/definition/english/flee?q=flee (accessed 21 March 2020).

35 See Council of Europe Enhancing the national legal framework in Ukraine for protecting the human rights of internally displaced persons (n 30) 19.

36 Article 1(1) of the 1969 OAU Refugee Convention defines a refugee as a person who 'owing to well- founded fear of being persecuted for reasons of race, religion, nationality, membership of a particular social group or political opinion, is outside the country of his nationality and is unable or, owing to such fear, is unwilling to avail himself of the protection of that country; or who, not having a nationality and being outside the country of his former habitual residence as a result of such events, is unable or, owing to such fear, is unwilling to return to it.' 1951 UN Refugee Convention (n 1), Article 1(2). Similar definition is contained in the 1969 OAU Refugee Convention (n 3), Article 1(1). See also Micah B Rankin 'Extending the limits or narrowing the scope? 
of International Child Abduction (Hague Convention). ${ }^{37}$ Under the Hague Convention, the phrase 'habitual residence' in variant forms, is used ten times but not defined. ${ }^{38}$ As with drafters of the instrument, national courts have been careful about giving a definition of 'habitual residence' that is cast in stone. ${ }^{39}$ In the famously cited English case of Re Bates, the English High Court made this point in emphasising that: ${ }^{40}$

It is greatly to be hoped that the courts will resist the temptation to develop detailed and restrictive rules as to habitual residence, which might make it as technical a term of art as common law domicile. The facts and circumstances of each case should continue to be assessed without resort to presumptions or pre-suppositions.

Deconstructing the OAU refugee definition thirty years on' Working Paper No 113, UN Refugee Agency (2005).

37 Hague Convention on the Civil Aspects of International Child Abduction (1996); Michelle M Kelly 'Taking Liberties: The Third Circuit Defines Habitual Residence Under the Hague Convention on International Child Abduction' (1996) 41(4) Villanova Law Review 1069; Katherine V Hung 'Recent Development: There's No Place Like Home. Determining Habitual Residence: Feder v. Evans-Feder' (1997) Georgia Journal of International and Comparative Law 487; Carshae D Davis 'The Gitter Standard: Creating a Uniform Definition of Habitual Residence under the Hague Convention on the Civil Aspects of International Child Abduction' (2006) 7(1) Chicago Journal of International Law 321; Tai Vivatvaraphol 'Back to Basics: Determining a Child's Habitual Residence in International Child Abduction Cases under the Hague Convention' (2009) 77(6) Fordham Law Review 3325; Robert G Spector 'A Guide to United States Case Law under the Hague Convention on the Civil Aspects of International Child Abduction' (2010) 12 Yearbook of Private International Law 139, 145; Stephen I Winter 'Home is Where the Heart Is: Determining "Habitual Residence" Under the Hague Convention on the Civil Aspects of International Child Abduction' (2010) 33 Washington University Journal of Law and Policy 351; Jeff Atkinson 'The Meaning of "Habitual Residence" Under the Hague Convention on the Civil Aspects of International Child Abduction and the Hague Convention on the Protection of Children' (2011) 63(4) Oklahoma Law Review 647; Morgan McDonald 'Home Sweet Home? Determining Habitual Residence Within the Meaning of the Hague Convention' (2018) 59(9) Boston College Law Review 427; Mo Zhang 'Habitual Residence v. Domicile: A Challenge Facing American Conflicts of Law' (2018) 70(2) Maine Law Review 162.

38 Hague Convention on the Civil Aspects of International Child Abduction (n 37).

39 Jeff Atkinson 'The Meaning of "Habitual Residence" Under the Hague Convention on the Civil Aspects of International Child Abduction and the Hague Convention on the Protection of Children' (n 37); Stephen I Winter 'Home is Where the Heart Is: Determining "Habitual Residence" Under the Hague Convention on the Civil Aspects of International Child Abduction' (n 37) 356.

40 Re Bates, No CA 122/89, High Court of Justice, Family Division, United Kingdom (1989); see also Rydder v Rydder, 49 F. $3 d 369$ (8th Circuit, 1995). 
Similarly, in the US case of Levesque v Levesque, the US District Court adopted a similar reasoning in emphasising that the 'intent is for the concept to remain fluid and fact based, without becoming rigid'. ${ }^{41}$ Though fluid, the notion is not without a degree of certainty. In Re Bates, the English High Court offers some useful guidance in explaining that for habitual residence to exist: ${ }^{42}$

There must be a degree of settled purpose. The purpose may be one or there may be several. It may be specific or general. All that the law requires is that there is a settled purpose. That is not to say that the propositus intends to stay where he is indefinitely. Indeed his purpose while settled may be for a limited period. Education, business or profession, employment, health, family or merely love of the place spring to mind as common reasons for a choice of regular abode, and there may well be many others. All that is necessary is that the purpose of living where one does has a sufficient degree of continuity to be properly described as settled.

Three pertinent points may be gleaned: an actual dwelling, the existence of a settled purpose which may either be specific or general and a degree of continuity which is not to be equated with permanence. ${ }^{43}$ Although the notion of habitual residence does not mean domicile, ${ }^{44}$ it is understood as more than mere presence. ${ }^{45}$ In Droit de la famille, the Superior Court of Quebec emphasised that it contemplates 'durable ties than mere residence' and 'not just where a person is passing through'. ${ }^{46}$

While the question of habitual residence is a factual consideration, it is imperative to emphasise that the legality of an individual's residence is not

${ }_{41}$ Levesque v Levesque, 816 F. Supp. 662 (District of Kansas, 1993).

42 The High Court, per Justice Waite, quoted from an earlier speech from Lord Scarman in $R v$ Barnet London Borough Council ex parte Shah regarding this statement as 'the governing principle for ascertaining the elements of habitual residence'. See Re Bates (n 40); $R$ v Barnet London Borough Council, ex parte Shah (1983) 2 A.C. 309, 314.

43 See Re J. (A Minor) (Abduction: Custody Rights) (1990) 2 A.C. 562; Vv B (A Minor) (Abduction) (1991) 1 FLR 266; In re Ponath, 829 F. Supp. 363 (District of Utah, 1993); Feder v Evans-Feder, 63 F. 3d 217 (3rd Circuit, 1995); Friedrich v Friedrich, 78 F. 3d 1060 (Sixth Circuit, 1996).

44 Tal Schreier 'The Expanded Refugee Definition' in Fatima Khan and Tal Schreier Refugee Law in South Africa (Juta, 2014) 88-89; Michelle Foster and Hélène Lambert International Refugee Law and the Protection of Stateless Persons (Oxford University Press, 2019) 135.

45 Tal Schreier 'The Expanded Refugee Definition' (n 44) 89.

46 Droit de la famille - 2617 [1997] R.D.F. 374; see also Gérald Goldstein The Concepts of Habitual Residence and Ordinary Residence in Light of Quebec Civil Law, the Divorce Act and the Hague Conventions of 1980 and 1996 (Family, Children and Youth Section Research Report, September 2006) https://www.justice.gc.ca/eng/rp-pr/ fl-lf/divorce/rhro_qc/pdf/rhro_qc.pdf (accessed 26 March 2020). 
necessarily a determinant of the existence of the notion of "place of habitual residence'. The notion of habitual residence should be understood as 'merely residence of some standing or duration'. ${ }^{47}$ As such, where an individual is, perhaps, a squatter on a piece of land or property - the factual consideration of his connection with such a place as opposed to whether such a stay is legal or otherwise should be the pertinent consideration.

\section{$5 \quad$ IN PARTICULAR}

A pertinent question which a consideration of this phrase raises is whether the inclusion of the phrase 'in particular' presupposes that the grounds upon which internal displacement may occur, as recognised in the description, are exhaustive or otherwise. In other words, does the phrase, 'in particular' entail specificity and does it create a finite list such that causes of internal displacement other than those specifically mentioned (namely: armed conflict, situations of generalised violence, violations of human rights, natural or human-made disasters) cannot be included. Kälin makes a pertinent submission, emphasising that the words 'in particular' indicate 'that the listed examples are not exhaustive'. ${ }^{48}$ While used to lay emphasis on specific root causes, it does not express finality. This rhetoric also gains support with reference to the provision of the Guiding Principles, particularly, principle 6(2)(c) which also recognises large-scale development projects as a root cause of internal displacement. ${ }^{49}$ However, this is not explicitly mentioned in the root causes recognised in the description.

\section{AS A RESULT OF OR IN ORDER TO AVOID}

While the description is not finite on the grounds of internal displacement, specific grounds are recognised as causes of internal displacement: armed conflict, situations of generalised violence, violations of human rights, natural or human-made disasters. This section examines these grounds.

47 Describing the notion within the context of refugee law, Grahl-Madsen emphasises that there is 'no need to prove any animus manendi, because "habitual residence" does not mean domicile, but merely residence of some standing or duration.' Atle Grahl-Madsen The Status of Refugees in International Law: Refugee Character' (Sijthoff, 1966).

4.

48 Walter Kälin 'Guiding Principles on Internal Displacement: annotations' (n 21)

49 The Guiding Principles (n 20), Article 6(2)(c). 


\section{A Armed Conflict}

From the start, it is useful to distinguish armed conflicts as a ground, separate from the typical usage of the word conflict, which is broader in denotation. In the case of the Prosecutor $v$ Jean Paul Akayesu (Akayesu), the International Criminal Tribunal for Rwanda (ICTR) observed that the words armed conflict 'suggests the existence of hostilities between armed forces organized to a greater or lesser extent'.${ }^{50}$ However, this description does not draw a distinction between the types of armed conflicts.

In the Prosecutor $v$ Duško Tadić, the International Criminal Tribunal for the former Yugoslavia (ICTY) gives a fairly detailed description, indicating that 'armed conflict exists whenever there is a resort to armed force between States or protracted armed violence between governmental authorities and organized armed groups or between such groups within a State'. ${ }^{51}$ From this description, and international humanitarian law generally, two forms of armed conflicts are established: international armed conflict (IAC) between states and non-international armed conflict (NIAC) between states and armed groups or between armed groups. Generally, in NIAC, two criteria are required: the organisation of armed groups and the intensity of the hostilities. ${ }^{52}$ While these criteria always apply in NIAC, Additional Protocol II and the Rome Statute of

50 The Prosecutor $v$ Jean Paul Akayesu International Criminal Tribunal for Rwanda, Trial Chamber 1 (ICTR-96-4-T) (2 September 1998), para 620.

51 The Prosecutor $v$ Duško Tadić International Criminal Tribunal for the former Yugoslavia, Appeals Chamber (IT-94-1-AR72) (2 October 1995), para 70; see also The Prosecutor $v$ Ramush Haradinaj, Idriz Balaj and Lahi Brahimaj International Criminal Tribunal for the former Yugoslavia, Trial Chamber (IT-04-84-T) (3 April 2008), para 37; see also Anthony Cullen 'The Parameters of Internal Armed Conflict in International Humanitarian Law' (2004) 12 University of Miami International and Comparative Law Review 189, 202-203; Claus Kress 'War Crimes Committed in Non-International Armed Conflict and the Emerging System of International Criminal Justice' (2000) 30 Israel Yearbook on Human Rights 103.

52 In the Prosecutor $v$ Callixte Mbarushimana, the International Criminal Court (ICC) Pre-Trial Chamber reinforced this point emphasising that ' $[\mathrm{a}] \mathrm{s}$ to whether the conflict can be qualified as non-international in character, Article 8(2)(d) and (f) of the Statute requires such conflict reach a certain level of intensity which exceeds that of "internal disturbances and tensions, such as riots, isolated and sporadic acts of violence or other acts of similar nature". Furthermore, the designation "conflicts of a non-international character" applies to armed conflicts that take place in the territory of a state, when there is a protracted armed conflict between government authorities and organised armed groups or between such groups. Consistent with the case law of the Chamber, for the purpose of Article 8(2)(f) of the Statute, an organised armed group must have "the ability to plan and carry out military operations for a prolonged period of time".' See The Prosecutor v Callixte Mbarushimana International Criminal Court, Pre-Trial Chamber I (ICC-01/04-01/10) (16 December 2011), para 103. 
the International Criminal Court (Rome Statute) incorporate additional thresholds in the description of NIAC.

Article 8(2)(f) of the Rome Statute incorporates an element of 'protraction' to the armed conflict which seeks to distinguish NIAC from internal disturbances and tensions, such as riots, isolated and sporadic acts of violence or other acts of a similar nature'. ${ }^{53}$ While it would appear that the description offered in the Rome Statute benefited from decades of legal evolution since the development of the Geneva Conventions, what protraction implies is not clearly defined. The ICC Trial Chamber in the Prosecutor v Jean-Pierre Bemba Gombo acknowledged that "the concept of "protracted conflict" has not been explicitly defined in the jurisprudence of this Court', but did not engage in defining the concept. ${ }^{54}$ In the Prosecutor $v$ Thomas Lubanga Dyilo, the Pre-Trial Chamber expressed an opinion on 'protracted armed conflict between [...] [organized armed groups]' as emphasising 'the need for the armed groups in question to have the ability to plan and carry out military operations for a prolonged period of time'. ${ }^{55}$ The approach of the ICC has often been to focus its description of 'protraction' on one of the elements of NIAC: the organisation of the armed group. Arguably, the element of protraction does not appear to introduce a third criterion. ${ }^{56}$ This approach is quite similar to the way in which the ICTY tended to overlook temporality by connecting protraction with one of the elements of NIAC, the element of intensity. The ICTY

53 Rome Statute of the International Criminal Court (1998), Article 8(2)(f).

54 The Prosecutor v Jean-Pierre Bemba Gombo International Criminal Court, Trial Chamber III (ICC-01/05-01/08) (21 March 2016), para 139.

55 The Prosecutor $v$ Thomas Lubanga Dyilo International Criminal Court, Pre-Trial Chamber I (ICC-01/04-01/06) (29 January 2007), para 234; this was reinforced in The Prosecutor v Omar Hassan Ahmad Al Bashir ('Omar Al Bashir') International Criminal Court, Pre-Trial. Chamber I (ICC-02/05-01/09) (4 March 2009), para 60; see William Schabas The International Criminal Court: A Commentary on the Rome Statute (Oxford University Press, 2010) 206.

56 The ICRC also expresses this fact as it observes that " $\mathrm{t}]$ he addition of the word "protracted" to armed conflict seems to be redundant since protracted violence is a constituent element of an armed conflict not of an international character'. See International Committee of the Red Cross Working Paper (29 June 1999) 60-61 http:// www.iccnow.org/documents/ICRCWorkPaperArticle8Para2e.pdf (accessed 21 March 2020); see also Caitlin Dwyer and Tim McCormack 'Conflict Characterisation' in Rain Liivoja and Tim McCormack Routledge Handbook of the Law of Armed Conflict (Routledge, 2016) 50, 60-61. 
offered a significant insight on this in the case of the Prosecutor $v$ Ramush Haradinaj, Idriz Balaj and Lahi Brahimaj, when it emphasised that: ${ }^{57}$

The criterion of protracted armed violence has therefore been interpreted in practice, including by the Tadić Trial Chamber itself, as referring more to the intensity of the armed violence than to its duration. Trial Chambers have relied on indicative factors relevant for assessing the "intensity" criterion, none of which are, in themselves, essential to establish that the criterion is satisfied. These indicative factors include the number, duration and intensity of individual confrontations; the type of weapons and other military equipment used; the number and calibre of munitions fired; the number of persons and type of forces partaking in the fighting; the number of casualties; the extent of material destruction; and the number of civilians fleeing combat zones. The involvement of the UN Security Council may also be a reflection of the intensity of a conflict.

Additional Protocol II introduces another threshold as it defines its material application to armed conflicts: ${ }^{58}$

which take place in the territory of a High Contracting Party between its armed forces and dissident armed forces or other organized armed groups which, under responsible command, exercise such control over a part of its territory as to enable them to carry out sustained and concerted military operations and to implement this Protocol.

This provision establishes a higher threshold in the description of NIAC. It introduces the criteria that an armed conflict must be between states and dissident armed forces or other armed groups - armed groups must exercise control over a part of a state's territory and be under a responsible command. The requirement that armed conflicts must be between states and dissident forces or armed groups excludes armed conflicts between organised armed groups themselves, for instance, in situations of a failed state. Moreover, the requirement that an armed group must exercise control raises the issue of quantification. However, this control has been construed more with respect to the quality of control to 'maintain sustained and concerted military operations'

\footnotetext{
57 The Prosecutor v Ramush Haradinaj, Idriz Balaj and Lahi Brahimaj (n 51), para 49.

58 Protocol Additional to the Geneva Conventions of 12 August 1949 and Relating to the Protection of Victims of Non-international Armed Conflict (Additional Protocol II) (8 June 1977), Article 1(1).
} 
rather than the expanse of control. ${ }^{59}$ In the Prosecutor v Jean Paul Akayesu, the ICTR emphasised this point in stating that: ${ }^{60}$

armed forces must be able to dominate a sufficient part of the territory so as to maintain sustained and concerted military operations and to apply Additional Protocol II. In essence, the operations must be continuous and planned. The territory in their control is usually that which has eluded the control of the government forces.

The element of responsible command also creates a higher threshold in the categorisation of armed groups and entails a level of organisation 'including the possibility to impose discipline and the ability to plan and carry out military operations' ${ }^{61}$ However, in armed conflict situations where Additional Protocol II does not apply, international humanitarian law is clear on the applicability of Common Article 3 which reinforces non-discrimination and humane treatment as minimum threshold for individuals 'taking no active part in ... hostilities including members of armed forces who have laid down their arms and those placed "hors de combat" by sickness, wounds, detention or any other cause'. ${ }^{62}$

\section{B Situations of Generalised Violence}

Much of the discussion on situations of generalised violence has emerged in the refugee law context, specifically in relation to Latin America owing to the recognition of generalised violence in the Cartagena Declaration. The UNHCR's Guidelines on International Protection describes generalised violence as: ${ }^{63}$

violence that is widespread, affecting large groups of persons or entire populations, serious and/or massive human rights violations, or events characterized by the loss

\footnotetext{
59 Sandesh Sivakumaran The Law of Non-International Armed Conflict (Oxford University Press, 2012) 186.

60 The Prosecutor v Jean Paul Akayesu (n 50), para 626.

${ }_{61}$ The Prosecutor v Jean-Pierre Bemba Gombo International Criminal Court, Trial Chamber II (ICC-01/05-01/08) (15 June 2009), para 234.

62 See Geneva Convention for the Amelioration of the Condition of the Wounded and Sick in Armed Forces in the Field (12 August 1949) (First Geneva Convention); Geneva Convention for the Amelioration of the Condition of Wounded, Sick and Shipwrecked Members of Armed Forces at Sea (12 August 1949) (Second Geneva Convention); Geneva Convention Relative to the Treatment of Prisoners of War of 12 August 1949 (Third Geneva Convention); Geneva Convention Relative to the Protection of Civilian Persons in Time of War (12 August 1949) (Fourth Geneva Convention).

${ }_{63}$ Guidelines on international protection no 12: claims for refugee status related to situations of armed conflict and violence under Article 1A(2) of the 1951 Convention
} 
of government control and its inability or unwillingness to protect its population - including situations characterized by repressive and coercive social controls by non-state actors, often pursued through intimidation, harassment and violence.

Situations of generalised violence include various forms of indiscriminate violence that may be perpetuated either by state authorities or non-state actors. In Central America, this form of violence has mostly emerged from activities of gangs (maras). In El Salvador, for instance, the issue of gang violence has become a significant problem 'with as many as 600,000 in a country of about 6 million believed to be in the groups' extended networks, including family members of free and imprisoned gang members'. ${ }^{64}$ Generalised violence may also emerge from election violence as with the case of the 2007/2008 post-election violence in Kenya. ${ }^{65}$

\section{C Violations of Human Rights}

Given the rich glossary of human rights norms at various levels, human rights provide a comprehensive lens through which to consider a wide range of potential root causes of internal displacement, not explicitly mentioned in the description. This ranges from displacement due to harmful practices to situations of forced evictions. It is pertinent to reinforce the fact that violations of human rights may arise from national, regional and international instruments. The recognition of violations of human rights as a root cause of internal displacement draws on the pertinence of state obligations to protect human rights. This form of internal displacement is generally not permissible in international law as violations represent infraction on obligations and are a breach of international legal norms.

\section{D Natural or Human-Made Disasters}

Central to the notion of disasters is the fact that they are catastrophic events that result in pervasive human suffering and seriously affect the functioning of

and/or 1967 Protocol relating to the Status of Refugees and the regional refugee definitions (2016), para 58.

${ }_{64}$ Sarah Kinosian 'El Salvador's Gang Violence: Turf Wars, Internal Battles and Life Defined by Invisible Borders' Security Assistance Monitor (News) (10 February 2016); see generally David J Cantor 'As Deadly as Armed Conflict? Gang Violence and Forced Displacement in the Northern Triangle of Central America' (2016) 23(34) Agenda Internacional 77.

65 See United Nations High Commissioner for Human Rights Report from OHCHR fact-finding mission to Kenya (6-28 February 2008). 
societies. ${ }^{66}$ The Guiding Principles recognise natural or human-made disasters. While these forms of disasters may be linked, there are also specific situations where they could be separate. For instance, natural disasters could emerge from earthquakes, droughts, hurricanes and torrential floods. Moreover, human-made disasters may emerge from nuclear explosions, oil spillages and mining accidents. However, there is often the perception that natural disasters are not always natural as they are precipitated by human activities. A pertinent manifestation of this is the issue of climate change.

In recent years, climate change has emerged as a significant link between natural and human-made disasters, given the nexus between anthropogenic forcing and the exacerbation of natural disasters. Since the 1990s, when the nexus between climate change and human mobility was first mooted, ${ }^{67}$ a significant body of knowledge has emerged linking climate change to human mobility. It is estimated that by 2050 , there will be more than 143 million internal migrants due to climate change, with Africa and South Asia likely to be the most impacted as 86 and 40 million people may be affected in countries within these regions respectively. ${ }^{68}$ The Cancun Agreement recognises displacement as one of the dimensions of climate change and human mobility and emphasises the need for states to take measures to address this impact. ${ }^{69}$ Emerging from the literature on climate change and internal displacement are issues of climate-exacerbated disasters, climate development-induced displacements and climate-related internal conflicts. ${ }^{70}$ Unless greenhouse emissions are cut by 7.6 percent between 2020 and 2030 , the fact that the $1.5^{\circ} \mathrm{C}$ target of the Paris Agreement may be missed ${ }^{71}$ makes attention to this root cause an imperative.

66 See Draft Articles on the Protection of Persons in the Event of Disasters, adopted by the International Law Commission at the 68th session (2016), Article 3(a).

67 See Intergovernmental Panel on Climate Change Climate Change: the IPCC impacts assessment (Australian Government Publishing Services, 1990) 5-9.

68 In Latin America, at least 17 million people may be affected. World Bank Groundswell: Preparing for Internal Climate Migration (World Bank Publications, 2018).

${ }_{69}$ The Cancun Agreements: outcome of the work of the Ad Hoc Working Group on Long-term Cooperative Action under the Convention, adopted by the Conference of the Parties Decision 1/CP.16 at its sixteenth session in Cancun, Mexico (29 November-10 December 2010), para 14(f).

${ }_{70}$ See Romola Adeola 'Climate change, internal displacement and the Kampala Convention' Policy Briefing on Climate Change and Migration, Africa Portal (2020).

${ }^{71}$ 'Cut global emissions by 7.6 percent every year for next decade to meet $1.5^{\circ} \mathrm{C}$ Paris target - UN Report' UNFCCC (Press Release, 26 November 2019). 


\section{WHO HAVE NOT CROSSED AN INTERNATIONALLY RECOGNISED STATE BORDER}

One of the definite distinctions between refugees and IDPs is the destination of movement from the initial point of departure. While refugees move outside the border of states, IDPs remain within state borders and as such are within the jurisdiction of the state in which displacement occurs. While initially captured in the phrase 'own country' in the UNSG's Analytical Report, the situation in the former Yugoslavia and former USSR during the 1990s with the dissolution of these states made the concept of 'own country' less preferable. ${ }^{72}$

Recourse to 'internationally recognized state border' captures the internal element differently. However, it is no less ambiguous given the fact that it introduces the element of statehood which is yet still contested, for instance, in parts of former USSR with states such as Abkhazia and South Ossetia. Another pertinent issue relates to situations where a displaced person crosses an internationally recognised state border while transiting to another region of the initial state. For instance, an individual who moves across the Irish border from Ireland into Northern Ireland and back into Ireland will have potentially crossed an internationally recognised state border as between the UK and Ireland. If the element of 'not having crossed an internationally recognized state border' is applied strictly, such a situation may imply that having crossed an internationally recognised state border, such an individual may not be considered an IDP. However, Kälin argues that the phrase should be 'understood in a broad sense' ${ }^{73}$ Such transit situations will, in essence, not affect the description of the individual as an IDP. ${ }^{74}$

\section{$8 \quad$ CONCLUSION}

Understanding who IDPs are is useful for the provision of adequate protection and humanitarian assistance. While the description of the Guiding Principles affords an understanding, it also raises pertinent questions relevant to practical application. This chapter has examined some of these practical ramifications, providing a useful lens for engaging the description of IDPs. However, it is imperative that this description is not regarded as a strict legal definition,

\footnotetext{
72 Catherine Phuong The International Protection of Internally Displaced Persons (n 13) 35.

73 Walter Kälin ‘Guiding Principles on Internal Displacement: annotations’ (n 21) 74 ibid.
} 3. 
rather as a fluid optic for practically identifying IDPs distinctively from other categories of persons such as refugees. This chapter also examines the various root causes of internal displacement within the context of the description. It is pertinent to emphasise that this description in the Guiding Principles is broad, leaving room for the inclusion of other emerging root causes of internal displacement. 